\title{
Selective depletion of testicular macrophages and prevention of Leydig cell repopulation after treatment with ethylene dimethane sulfonate in rats
}

\author{
F. Gaytan ${ }^{1}$, C. Bellido ${ }^{2}$, C. Morales ${ }^{3}$, C. Reymundo ${ }^{3}$, \\ E. Aguilar ${ }^{2}$ and N. van Rooijen ${ }^{4}$ \\ Departments of ${ }^{1}$ Cell Biology, ${ }^{2}$ Physiology, and ${ }^{3}$ Pathology, University of Córdoba, Spain; and \\ ${ }^{4}$ Department of Cell Biology, Vrije Universiteit, Amsterdam, The Netherlands
}

\begin{abstract}
Testicular macrophages were selectively eliminated with dichloromethylene diphosphonatecontaining liposomes $\left(\mathrm{Cl}_{2} \mathrm{MDP}-\mathrm{lp}\right)$ to study the role of these cells in the repopulation of Leydig cells after treatment with ethylene dimethane sulfonate (EDS). Right testes were injected with $\mathrm{Cl}_{2} \mathrm{MDP}$-lp to deplete macrophages and left testes were injected with sodium chloride and served as controls. Injection of $\mathrm{Cl}_{2} \mathrm{MDP}-\mathrm{lp}$ produced a $97 \%$ reduction in the number of macrophages 10 days after treatment. Twenty-one days after destruction of the existing Leydig cells with EDS, abundant differentiating Leydig cells were present in the left (macrophage-containing) testes. On the contrary, in the right (macrophage-depleted) testes, differentiating Leydig cells were scarce, and was $3 \%$ of that found in the control testes. The inhibition of Leydig cell repopulation in macrophage-depleted testes was more evident at 30 days after EDS treatment, when the number of Leydig cells in the right testes was $1 \%$ of that found in control testes. The lack of Leydig cell development was also indirectly shown by the lower mass and more atrophic seminiferous epithelium of the right testes, as well as the decreased weight of the ipsilateral epididymis compared with the left testes. These results indicate that testicular macrophages are central to the proliferation and differentiation of new Leydig cells after EDS treatment, and point out the significance of paracrine regulatory mechanisms in rat testes.
\end{abstract}

\section{Introduction}

Testicular function is under the control of the hypothalamicpituitary axis. However, it has become evident that actions of gonadotrophin in the testis are modulated by local factors and by cell-cell interactions. Several reviews on the paracrine and autocrine regulation of the testes have been published (Sharpe, 1986, 1990; Saez et al., 1987; Skinner, 1991; SpiteriGrech and Nieschlag, 1993) and major emphasis has been given to interactions between Leydig cells and Sertoli cells.

Macrophages are a numerically important component of the testicular interstitium (Miller et al., 1983; Dirami et al., 1991) and are a potential source of cytokines in the testes. Several lines of evidence suggest that macrophages play important roles in testicular paracrine regulation. (i) Macrophages are morphologically (Miller et al., 1983) and functionally (Bergh, 1985) coupled to Leydig cells. (ii) Classic secretory products of macrophages, such as interleukin-I (IL-1) (Le and Vilcek, 1987), tumour necrosis factor $\alpha$ (TNF- $\alpha$ ) (Xiong and Hales, 1993), and transforming growth factor- $\alpha$ (TGF- $\alpha$ ) (Rappolee et al., 1988) act as local modulators of Leydig cell function (Welsh and Hsueh, 1982; Calkins et al., 1988; Verhoeven et al., 1988; Mauduit et al., 1992; Meikle et al., 1992; Xiong and Hales,

Received 7 September 1993.
1993). Furthermore, macrophage-conditioned medium increases testosterone secretion in vitro (Yee and Hutson, 1985). (iii) Macrophages accumulate in the testis during prepubertal development, in parallel with the proliferation-differentiation of Leydig cells (Hutson, 1990). Treatment of young rats with gonadotrophins increases the concentration of Leydig cells and macrophages (Raburn et al., 1991). (iv) Some macrophagederived cytokines, such as IL-1 $\beta$ (Xiong et al., 1991) and TGF- $\alpha$, (Rappolee et al., 1988) stimulate DNA synthesis in immature Leydig cells in culture (Khan et al., 1992a, b).

Treatment with ethylene dimethane sulfonate (EDS) destroys rat Leydig cells (Kerr et al., 1985; Molenaar et al., 1985; Bartlett et al., 1986; Jackson et al., 1986; Morris et al., 1986). A new Leydig cell population develops in the following weeks, and this model has been widely used to assess Leydig cell differentiation in rats (Jackson et al., 1986; Molenaar et al., 1986; Kerr et al., 1987; Teerds et al., 1990; Gaytan et al., 1992). Alternatively, testicular macrophages can be depleted with dichloromethylene diphosphonate-containing liposomes $\left(\mathrm{Cl}_{2} \mathrm{MDP}-\mathrm{lp}\right.$ ) (Bergh et al., 1993a), which is a powerful tool for studying the physiological role of these cells.

We used these techniques to study the role of testicular macrophages in the proliferation-differentiation of Leydig cells in vivo. 
Box 1. Scheme of experimental design

\begin{tabular}{|c|c|c|c|c|c|c|c|}
\hline $\begin{array}{l}\text { Days after } \mathrm{Cl}_{2} \mathrm{MDP}-\mathrm{lp} \text { or } \\
\mathrm{NaCl} \text { treatment }\end{array}$ & 8 & 10 & 13 & 29 & 31 & 38 & 40 \\
\hline \multirow{3}{*}{30 Rats } & TB (5) & $\mathrm{Sc}(5)$ & & & & & \\
\hline & & \multirow{4}{*}{ EDS (20) } & $\mathrm{Sc}(5)$ & & & & \\
\hline & & & & & & TB (5) & Sc (5) \\
\hline \multirow[t]{3}{*}{$\begin{array}{l}\text { Right testes } \mathrm{Cl}_{2} \mathrm{MDP}-\mathrm{lp} \\
\text { Left testes } \mathrm{NaCl}\end{array}$} & & & & & Sc (5) & & \\
\hline & & & & TB (5) & Sc (5) & & \\
\hline & & Veh (5) & & TВ (5) & Sc (5) & & \\
\hline $\begin{array}{l}\text { Days after EDS or } \\
\text { vehicle treatment }\end{array}$ & & & 3 & 19 & 21 & 28 & 30 \\
\hline
\end{tabular}

TB: trypan blue: $2 \mathrm{ml} 3 \%$ i.p.; EDS: $75 \mathrm{mg}$ ethylene dimethane sulfonate $\mathrm{kg}^{-1}$ i.p.; Veh (Vehicle): DMSO:water 1:3; Cl.MDP-Ip; dichloromethylene diphosphonate-containing $\left(\mathrm{Cl}_{2} \mathrm{MDP}\right)$ liposomes $150 \mu \mathrm{l}$ intratesticular. $\mathrm{NaCl}: 150 \mu \mathrm{l} 0.9 \%(\mathrm{w} / \mathrm{v})$ intratesticular. Sc: day on which animals were killed. The number of rats is given in parentheses.

\section{Materials and Methods}

\section{Animals}

Thirty adult male Wistar rats $(300-350 \mathrm{~g})$ were used. Animals were maintained under controlled light and temperature and had free access to food and water.

\section{Chemicals}

Dichloromethylene diphosphonate $\left(\mathrm{Cl}_{2} \mathrm{MDP}\right)$-containing liposomes were prepared as described by van Rooijen (1989) and $\mathrm{Cl}_{2} \mathrm{MDP}$ was a gift from Boehringer Mannheim $\mathrm{GmbH}$ (Mannheim). Phosphatidylcholine (LIPOID E PC) was a gift from LIPOID KG (Ludwigshafen).

Ethylene dimethane sulfonate (EDS) was synthesized following the method of Jackson and Jackson (1984).

\section{Experimental design}

A scheme of experimental design is shown in Box 1 .

Thirty rats were injected intratesticularly with $150 \mu \mathrm{l}$ $\mathrm{Cl}_{2} \mathrm{MDP}$-containing liposomes (right testis) and with $150 \mu \mathrm{l}$ of $0.9 \% \mathrm{NaCl}$ (left testis) under light ether anaesthesia, using the method described by Bergh et al. (1993a). Previous studies have shown that there were no differences between PBS-containing liposomes and $\mathrm{NaCl}$ treatment (Bergh et al., 1993a).
After 10 days, five animals were killed by decapitation; these animals had received an i.p. injection of $2 \mathrm{ml} 3 \%$ trypan blue in saline (Miller et al., 1983) $48 \mathrm{~h}$ previously to label testicular macrophages. The other animals were injected i.p. with $75 \mathrm{mg}$ EDS $\mathrm{kg}^{-1}$ body weight in DMSO:water (1:3) (20 rats) or vehicle (five rats).

On day 3 after EDS treatment, five animals were killed, and the other animals were killed on day 21 after EDS or vehicle treatment. Five other EDS-treated rats were killed 30 days after treatment. Five animals per group received an i.p. injection of trypan blue $48 \mathrm{~h}$ before they were killed.

\section{Tissue processing}

The testes and epididymides were carefully dissected. The testes were weighed and fixed for $48 \mathrm{~h}$ in Bouin-Hollande's fluid. After immersion in the fixative, small incisions were made in the tunica albuginea to facilitate fixation. Slabs perpendicular to the longest axis of the organ were then cut and they were dehydrated and embedded in paraffin wax. In all cases, right and left organs were considered separately. Sections, $5 \mu \mathrm{m}$, were cut and stained with haematoxylin and eosin or nuclear red, and viewed under a light microscope.

\section{Cell counting procedures}

The different cell types were counted relative to the number of Sertoli cell nuclei following the methods of Teerds et al. Downloaded from Bioscientifica.com at 04/26/2023 11:15:24AM 

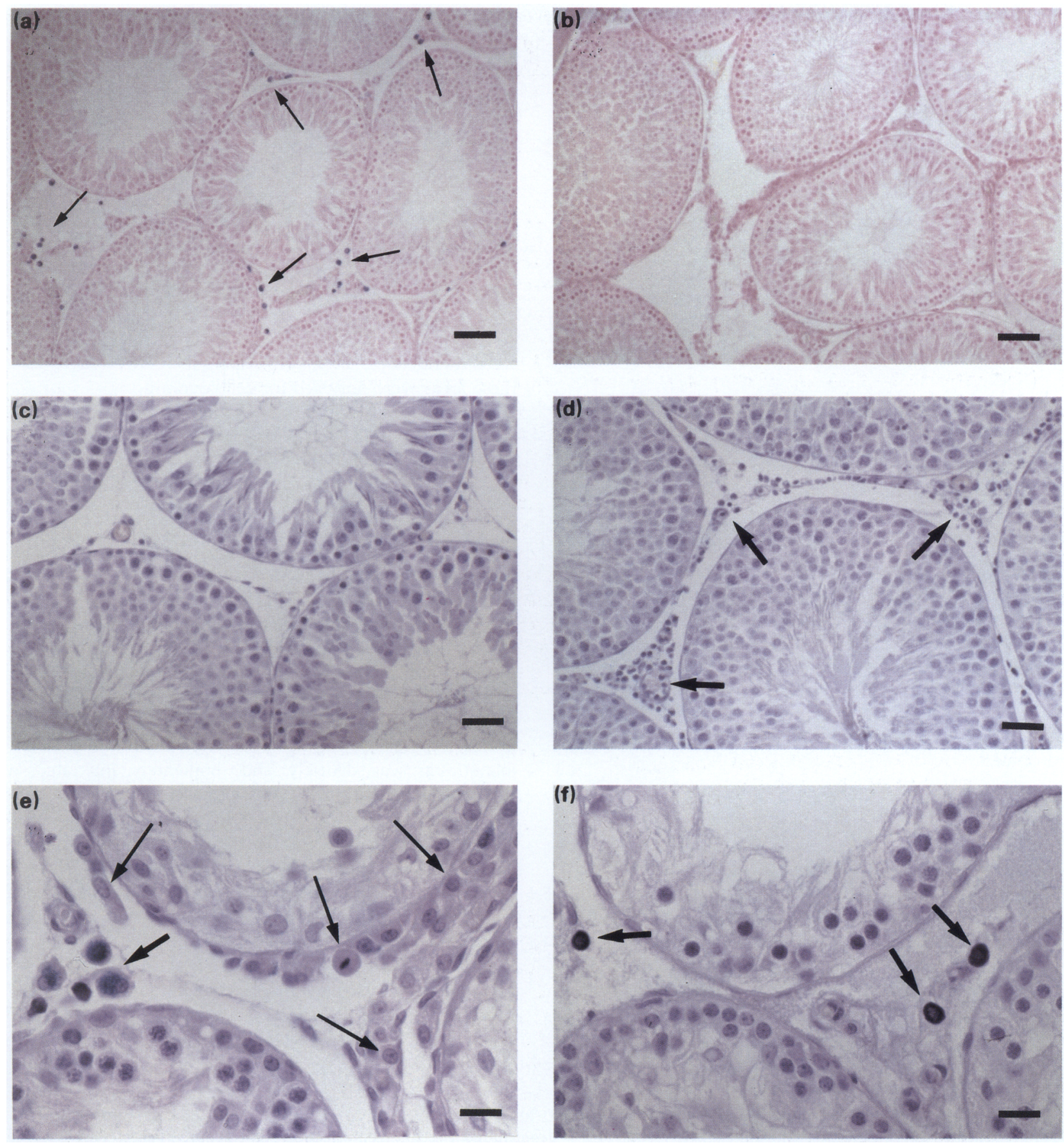

Fig. 1. Sections from the left $\left(\mathrm{NaCl}\right.$-injected) (a,c,e) and right (dichloromethylene diphosphonate-containing $\left(\mathrm{Cl}_{2} \mathrm{MDP}\right)$-liposome-injected) (b, $\left.d, f\right)$ testes. $(a, b)$ Ten days after treatment, macrophages (arrows) were abundant in the left testes and absent in the right testes. Trypan blue was injected $48 \mathrm{~h}$ before death. Counterstain nuclear red. Bars represent $50 \mu \mathrm{m}$. (c, d) Three days after ethylene dimethane sulfonate (EDS) treatment the testicular interstitium was devoid of Leydig cells, but inflammatory cells (arrows) were present in the right testes. Haematoxylin and eosin. Bars represent $30 \mu \mathrm{m}$. (e, f) Twenty-one days after EDS treatment. In the left testes abundant differentiating Leydig cells (long arrows) were found together with macrophages and mast cells (short arrow). In the right testes, mast cells (arrows) were the most prominent cell type. Haematoxylin and eosin. Bars represent $20 \mu \mathrm{m}$.

(1988, 1989b) and Gaytan et al. (1992). These counts have the advantage of being independent of volumetric changes of the tissue and have been used for the quantitation of interstitial cells after EDS treatment. Macrophages were counted in trypan blue injected rats. These cells showed large trypan-blue- containing vacuoles, either in nuclear red or haematoxylin and eosin stained sections. Leydig cells were recognized by their round to oval nuclei with a characteristic chromatin pattern. Mast cells showed intensely basophilic cytoplasm and central nuclei. 
The number of macrophages, Leydig cells and mast cells (counted only when the nuclei were present in the section) and the number of Sertoli cell nuclei (considered only when the nucleolus was present) were counted systematically in five randomly selected sections per testis, up to at least 1000 Sertoli cell nuclei per testis were scored.

\section{Statistical analyses}

Statistical analyses were performed by the Student's $f$ test for paired data for comparison between right and left organs, and by ANOVA and Tukey's multiple comparison methods when several groups were compared. Significance was considered at the 0.01 level.

\section{Results}

In a preliminary study, the Leydig cell:macrophage ratio was determined in semithin sections from intact rats and in paraffin wax sections from trypan blue-injected rats. In semithin sections stained with toluidine blue, macrophages can easily be identified by their pale-stained cytoplasm and nuclear characteristics. No differences were found between the methods (4.3 \pm 0.2 Leydig cells:macrophage in semithin sections versus $4.1 \pm 0.2$ Leydig cells:macrophages in trypan blue-injected rats). This finding indicated that the number of macrophages was not modified by systemically injected trypan blue and that all testicular macrophages have endocytic capacity. Macrophages were therefore counted by their ability to accumulate trypan blue.

\section{Effects of treatment with $\mathrm{Cl}_{2} \mathrm{MDP}$ liposomes}

Details on the effects of intratesticular injections of $\mathrm{Cl}_{2} \mathrm{MDP}-$ liposomes $\left(\mathrm{Cl}_{2} \mathrm{MDP}-\mathrm{lp}\right)$ or $\mathrm{NaCl}$ on macrophages have been reported by Bergh et al. (1993a). Ten days after treatment, abundant macrophages were present in the $\mathrm{NaCl}$-injected testes (Fig. Ia), whereas macrophages were scarce in $\mathrm{Cl}_{2} \mathrm{MDP}$ lp-injected contralateral testes (Fig. 1b). Occasionally, a few macrophages were found under the tunica albuginea in some rats. Some areas of tubule disruption at the site of the injection
Table 1. Number of macrophages and Leydig cells per 1000 Sertoli cell nuclei 10 days after treatment with $\mathrm{NaCl}$ (left testes) or dichloromethylene diphosphonate $\left(\mathrm{Cl}_{2} \mathrm{MDP}\right)$ liposomes (right testes)

\begin{tabular}{lrr}
\hline Treatment & Macrophages & Leydig cells \\
\hline $\mathrm{NaCl}$ & $297.6 \pm 7.2$ & $1204.6 \pm 56.6$ \\
$\mathrm{Cl}_{2} \mathrm{MDP}$-liposomes & $9.8 \pm 2.7^{*}$ & $1113.4 \pm 51.8$ \\
\hline
\end{tabular}

Data are means \pm SEM for five animals.

*Significantly different $(P<0.01)$ with paired $t$ test.

were found either in $\mathrm{Cl}_{2} \mathrm{MDP}-\mathrm{lp}$ or $\mathrm{NaCl}$ treated testes and these areas were not used for cell counting.

Macrophages in the $\mathrm{Cl}_{2} \mathrm{MDP}-\mathrm{lp}$ injected testes represent 3\% of the normal population. No significant changes in the number of Leydig cells were found (Table 1).

\section{Response to EDS treatment}

Three days after EDS treatment, the morphology of the testicular interstitium of the left $(\mathrm{NaCl}$-injected) testes was similar to that previously described for intact EDS-treated rats (Morris et al., 1986; Gaytan et al., 1992). Leydig cells were absent and macrophages were the most abundant cell type. No signs of inflammatory reaction were observed (Fig. Ic). An inflammatory reaction was seen in the contralateral $\left(\mathrm{Cl}_{2} \mathrm{MDP}\right.$ lp-injected) testes. Leydig cells were also absent and the interstitium was diffusely and moderately infiltrated with polymorphonuclear and mononuclear leucocytes (Fig. Id).

On day 21 after EDS teatment, the morphology of both testes was quite different. In the left ( $\mathrm{NaCl}$-injected) testes abundant differentiating Leydig cells were found. These cells showed round to oval nuclei and were located in peritubular or perivascular clusters (Fig. 1e). Mitotic figures were frequently seen. Mast cells were also abundant (Fig. 1e). On the contrary, in the right $\left(\mathrm{Cl}_{2} \mathrm{MDP}-\mathrm{lp}\right.$-injected) testes, differentiating Leydig cells and macrophages were extremely scarce; the most abundant interstitial cell type was the mast cell (Fig. 1f). The seminiferous epithelium of the right testes was more atrophic

Table 2. Number of macrophages, Leydig cells and mast cells per 1000 Sertoli cell nuclei 21 days after ethylene dimethane sulfonate (EDS) or vehicle treatment in rats treated with $\mathrm{NaCl}$ (left testes) or dichloromethylene diphosphonate $\left(\mathrm{Cl}_{2} \mathrm{MDP}\right)$-containing liposomes $\left(\mathrm{Cl}_{2} \mathrm{MDP}\right.$-lp) (right testes)

\begin{tabular}{lccc}
\hline Treatments & Macrophages* & Leydig cells & Mast cells \\
\hline $\mathrm{NaCl}+\mathrm{EDS}(n=10)$ & $362.5 \pm 15.9$ & $552.3 \pm 79.5$ & $252.6 \pm 10.3$ \\
$\mathrm{Cl} M \mathrm{MDP}-\mathrm{lp}+\mathrm{EDS}(n=10)$ & $29.6 \pm 12.4^{\mathrm{a}}$ & $19.2 \pm 15.9^{\mathrm{a}}$ & $279.1 \pm 20.2$ \\
$\mathrm{NaCl}+$ vehicle $(n=5)$ & $301.2 \pm 13.4$ & $1165.4 \pm 63.2^{\mathrm{b}}$ & $-^{+}$ \\
$\mathrm{Cl}_{2} \mathrm{MDP}-\mathrm{lp}+$ vehicle $(n=5)$ & $34.9 \pm 12.9^{\mathrm{a}}$ & $1079.2 \pm 76.2^{\mathrm{b}}$ & $-^{+}$ \\
\hline
\end{tabular}

Data are means \pm SEM.

*Macrophages were counted in five animals per group.

thess than I per 1000 Sertoli cell nuclei and located exclusively under the tunica albuginea.

aSignificant differences $(P<0.01)$ versus $\mathrm{NaCl}$-injected testes. ANOVA and Tukey's test.

${ }^{b}$ Significant differences $(P<0.01)$ versus EDS-treated rats. ANOVA and Tukey's test. 

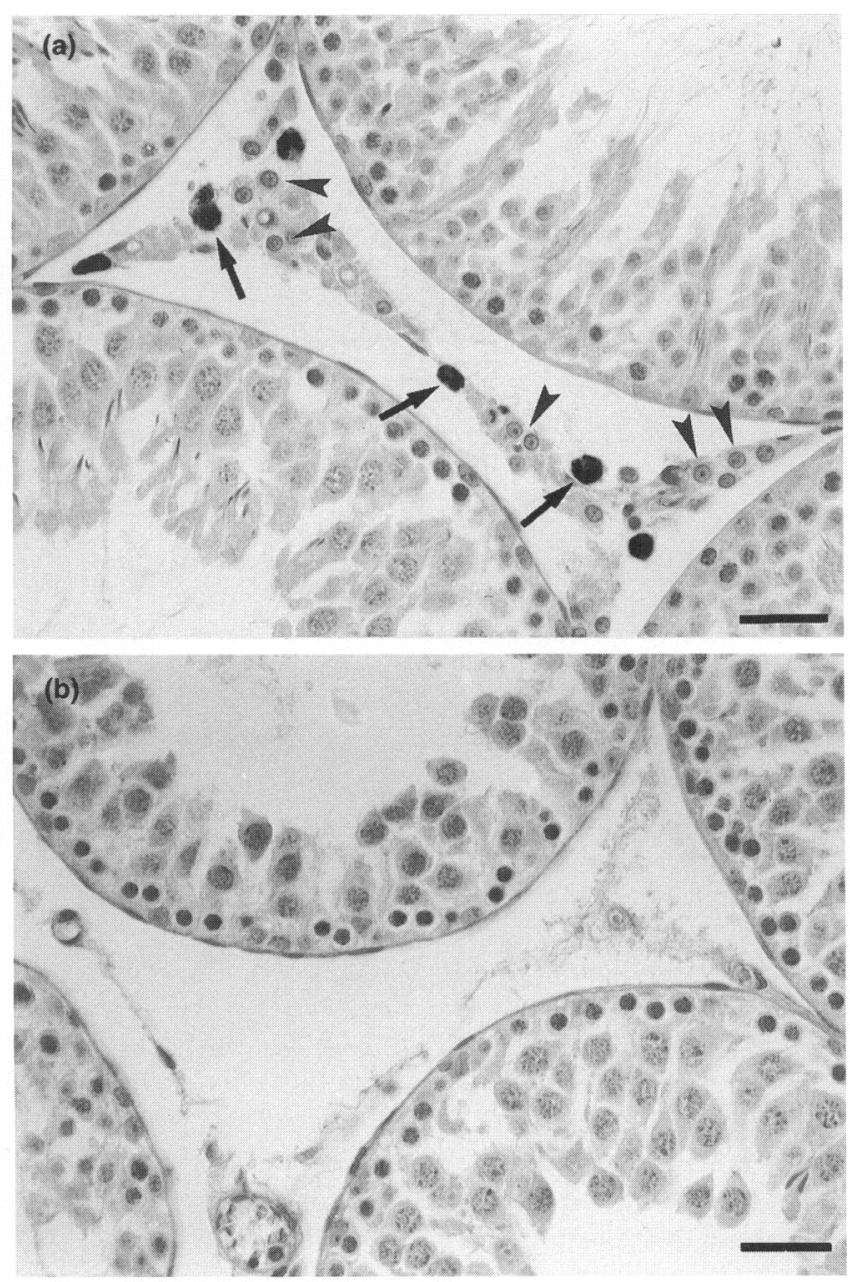

Fig. 2. Sections from left ( $\mathrm{NaCl}$-injected) (a) and right (dichloromethylene diphosphonate-containing ( $\mathrm{Cl}_{2} \mathrm{MDP}$-lp)-injected) (b) testes at 30 days after ethylene dimethane sulfonate (EDS) treatment. Abundant trypan blue-labelled macrophages (arrows) and Leydig cells (arrowheads) were present in the left testes, whereas they are absent in the right testes. Counterstaining with neutral red. Bars represent $40 \mu \mathrm{m}$.

than that in the left testes, and no signs of inflammatory reaction or interstitial fibrosis were observed.

$\mathrm{Cl}_{2} \mathrm{MDP}$-lp-injected testes showed significantly fewer macrophages (about $8 \%$ of the contralateral testes) and Leydig cells (about $3 \%$ of the contralateral testes), whereas no significant differences were found in the number of mast cells (Table 2). On day 30 after EDS treatment, the $\mathrm{NaCl}$-injected testes had abundant differentiated Leydig cells and macrophages (Fig. 2a). On the contrary, both cell types were scarce in the contralateral $\left(\mathrm{Cl}_{2} \mathrm{MDP}\right.$-Ip-injected) testes (Fig. 2b). Testes injected with $\mathrm{Cl}_{2} \mathrm{MDP}-\mathrm{lp}$ had significantly $(P<0.01)$ fewer macrophages and Leydig cells, whereas the number of mast cells was higher than in control testes (Table 3).

\section{Testicular and epididymal mass}

No significant differences were found for the testicular mass between $\mathrm{NaCl}$ and $\mathrm{Cl}_{2} \mathrm{MDP}$-lp-injected testes 10 or 31 days after treatment. However, in EDS-treated animals, testicular (Fig. 3) and epididymal (Fig. 4) masses were significantly lower in the $\mathrm{Cl}_{2} \mathrm{MDP}$-injected organs, 21 days after treatment. On day 30 after EDS treatment, macrophage-depleted testes showed a $34 \%$ decrease in mass compared with the contralateral, macrophage-containing testes $(1006 \pm 132$ versus $1530 \pm 140 \mathrm{mg}, P<0.01$, Student's $t$ test; $n=5$ ). The mass of the ipsilateral epididymis was $32 \%$ lower compared with the contralateral organs $(283 \pm 28$ versus $417 \pm 52 \mathrm{mg}, P<0.01$, Student's $t$ test; $n=5$ ).

\section{Discussion}

This study demonstrates that depletion of testicular macrophages prevents the development of new Leydig cells after EDS treatment. Repopulation of Leydig cells depends on $\mathrm{LH}$ (Molenaar et al., 1986), and does not occur in hypophysectomized EDS-treated rats (Teerds et al., 1989a; Gaytan et al., 1990) or by blocking pituitary secretion after EDS treatment with exogenous testosterone (Sharpe et al., 1988; Teerds et al., 1989b). The experimental approach used in the study reported here shows that inhibition of Leydig cell development was caused by changes in local regulatory mechanisms, and not by general endocrine alterations. This was indicated by the development of abundant Leydig cells in the contralateral, macrophage-containing, testes. These results point out the significance of paracrine regulatory mechanisms in the testis and the central role of macrophages in this system.

Macrophages play important roles in the regeneration of many cell types after tissue injury. For instance, macrophages are central to the wound-healing response which requires the proliferation of several regenerating cell types, through the secretion of several growth factors (Rappolee et al., 1988). Similarly, Leydig cell destruction with EDS led to the disposal of dead Leydig cells by macrophages (Jackson et al., 1986; Morris et al., 1986; Kerr et al., 1987) and the consequent regeneration of the Leydig cell population (Molenaar et al., 1986; Jackson et al., 1986). Previous studies have shown that macrophage-derived cytokines, such as IL-1 $\beta$ and TGF- $\alpha$, stimulate DNA synthesis in immature Leydig cells in vitro (Khan et al., 1992a, b). However, macrophages are not the only source of these cytokines in the testes. Other cell types, such as Sertoli cells (Syed et al., 1988) and peritubular-myoid cells (Skinner et al., 1989), also have the capacity to secrete these growth factors. The contribution of each cell type to the total amounts of IL-I and TGF- $\alpha$ in the testis, as well as their effects on the proliferative activity of Leydig cells in vivo, are not known.

Interstitial cell proliferation after EDS treatment follows a biphasic pattern. A first proliferative wave (involving many different cell types) occurs on days 2-3 after treatment (Teerds et al., 1990; Gaytan et al., 1992). It is thought that some of these proliferating mesenchymal cells correspond to undifferentiated Leydig cell precursors. From day 3 to day 18 after treatment, abundant morphologically recognizable Leydig cells are present (Jackson et al., 1986; Morris et al., 1986; Gaytan et al., 1992). In addition, testosterone concentrations reach normal values by day 21 (Bartlett et al., 1986). A second proliferative wave, involving mainly differentiating Leydig 
Table 3. Number of macrophages, Leydig cells and mast cells per 1000 Sertoli cell nuclei 30 days after ethylene dimethane sulfonate (EDS) treatment in rats treated with $\mathrm{NaCl}$ (left testes) or dichloromethylene diphosphonate $\left(\mathrm{Cl}_{2} \mathrm{MDP}\right)$-containing liposomes $\left(\mathrm{Cl}_{2} \mathrm{MDP}\right.$-lp) (right testes)

\begin{tabular}{lccc}
\hline Treatment & Macrophages* & Leydig cells & Mast cells \\
\hline $\mathrm{NaCl}$ & $327.3 \pm 12.4$ & $994.6 \pm 40.5$ & $210.7 \pm 20.1$ \\
$\mathrm{Cl}_{2} \mathrm{MDP}-\mathrm{lp}$ & $24.3 \pm 17.6^{\mathrm{a}}$ & $10.3 \pm 6.5^{\mathrm{a}}$ & $308.6 \pm 24.4^{\mathrm{a}}$ \\
\hline
\end{tabular}

Data are means $\pm \operatorname{SEM}(n=5)$.

* Macrophages were counted in five animals per group.

${ }^{a}$ Significant differences $(P<0.01)$ versus $\mathrm{NaCl}$-injected testes. Student's $t$ test for paired data.

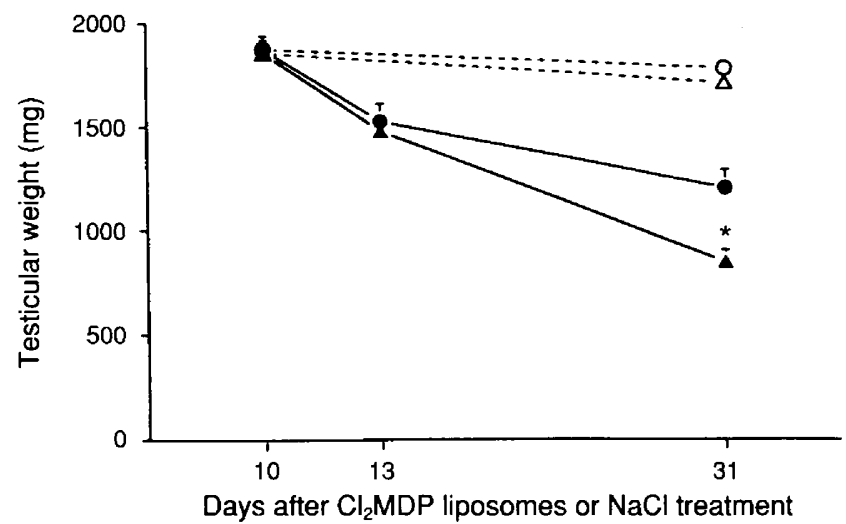

Fig. 3. Evolution of testicular weight in rats injected intratesticularly with $\mathrm{NaCl}$ in left testes $(\mathrm{O}, 0)$ or dichloromethylene diphosphonate containing $\left(\mathrm{Cl}_{2} \mathrm{MDP}\right)$-liposomes in right testes $(\triangle, \boldsymbol{\Delta})$ and with ethylene dimethane sulfonate $(\operatorname{EDS})(\boldsymbol{O}, \boldsymbol{\Delta})$ or vehicle $(O, \triangle)$ 10 days later. ${ }^{*}$ Significant difference $(P<0.01)$ by Student's $t$ test for paired data versus contralateral testes.

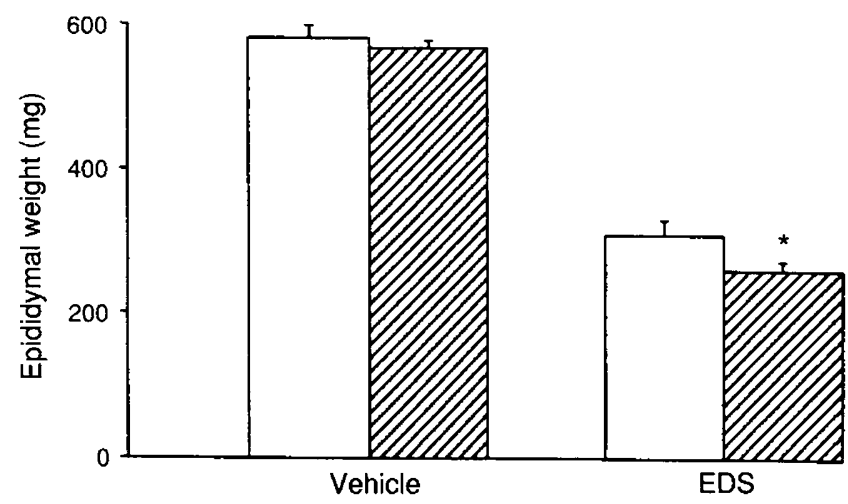

Fig. 4. Epididymal weight in rats injected intratesticularly with $\mathrm{NaCl}$ in left testes $(\square)$ or dichloromethylene diphosphonate containing $\left(\mathrm{Cl}_{2} \mathrm{MDP}\right)$-liposomes in right testes $(\square), 21$ days after treatment with ethylene dimethane sulfonate (EDS) or vehicle. *Significant differences $(P<0.01)$ by Student's $t$ test for paired data.

cells, occurs from day 18 to day 23 after treatment (Teerds et al., 1990; Gaytan et al., 1992).

The scarcity of recognizable Leydig cells in macrophagedepleted testes at least up to 30 days after EDS treatment could be due to inhibition of different steps: (i) the first proliferative wave and therefore the expansion or commitment of undiffer- entiated precursors; (ii) the differentiation of precursor cells to morphologically recognizable, LH-responsive, immature Leydig cells; (iii) the proliferative activity of differentiating Leydig cells. The stage of Leydig cell development that was inhibited was not determined in the study reported here and different experimental approaches are needed to test these possibilities. In normal conditions, macrophages are present throughout Leydig cell differentiation. It is noteworthy that the number of macrophages relative to Leydig cells was higher during Leydig cell repopulation (65.6 macrophages per 100 Leydig cells in $\mathrm{NaCl}$ injected testes, 21 days after EDS treatment) than in control testes (24.4 macrophages per 100 Leydig cells before EDS treatment), because fewer Leydig cells were present in these animals. In addition to Leydig cells, mast cells also proliferate and accumulate in the testicular interstitium after EDS treatment (Gaytan et al., 1990, 1992). In the study reported here, mast cell accumulation was not modified in macrophage-depleted testes at 21 days after treatment. The proliferation of different cell types may depend on different, sometimes overlapping, combinations of growth factors. This contention is in agreement with previous studies indicating that mast cell proliferation-differentiation in rat testes is related to the absence of fully differentiated Leydig cells (Gaytan et al., 1990, 1992). It is also in accordance with the existence of a large number of mast cells in macrophage-depleted testes, in which Leydig cells were absent at 30 days after EDS treatment.

An inflammatory response was present in macrophagedepleted testes 3 days after EDS treatment, whereas no signs of inflammatory reaction were found in the contralateral testes. This finding seems to indicate that testicular macrophages inhibit acute inflammatory reactions after massive cell death. It has been reported that hCG-induced inflammation-like response in the rat testis is enhanced in macrophage-depleted testes (Bergh et al., 1993b). Macrophages release several factors, such as TGF- $\beta$ and proopiomelanocortin-derived peptides (Wahl et al., 1989; Li et al., 1991), which inhibit polymorphonuclear leucocyte accumulation (Mason and van Epps, 1989). Whether this inhibitory action is limited to the testis or is also present in other tissues is unknown.

Surprisingly, infiltrating monocytes did not repopulate the testicular interstitium in macrophage-depleted testes, as the number of macrophages was equivalent in EDS or vehicletreated animals. Recovery of the macrophage population was slow: only $8 \%$ of the normal population was present 31 days after depletion, and this was not dependent on the presence of Leydig cells. 
The early inflammatory response found after EDS treatment seems to be time-limited since the stimulus (dead Leydig cells) had disappeared by day 3 after EDS treatment and no signs of inflammation or tissue damage (fibrosis) were found after 21 days. However, the possible disturbance of interstitial cell regeneration by acute inflammation cannot be disregarded from the data of the study reported here.

However, it is clear that macrophages play a crucial role in the repopulation of Leydig cells after EDS treatment. Additional studies are needed to determine the role of macrophages in the proliferation-differentiation of Leydig cells either during recovery from EDS treatment or during prepubertal development.

The authors are very grateful to J. Molina and P. Cano by their technical assistance.

\section{References}

Bartlett JMS, Kerr JB and Sharp RM (1986) The effect of selective destruction and regeneration of rat Leydig cells on the intratesticular distribution of testosterone and morphology of the seminiferous epithelium joumal of Andrology 7 240-253

Bergh A (1985) Effect of cryptorchidism on the morphology of testicular macrophages: evidence for a Leydig cell-macrophage interaction in the rat testis International Journal of Andrology 8 86-96

Bergh A, Damber JE and van Rooijen N (1993a) Liposome-mediated macrophage depletion: an experimental approach to study the role of testicular macrophages in the rat Joumal of Endocrinology $136407-413$

Bergh A, Damber JE and van Rooijen N (1993b) The human chorionic gonadotropin-induced inflammation-like response is enhanced in macrophage-depleted rat testes Journal of Endocrinology 136 415-420

Calkins JH, Sigel MM, Nankin HR and Lin T (1988) Interleukin-1 inhibits Leydig cell steroidogenesis in primary culture Endocrinology 123 I605-1610

Dirami G, Poulter LW and Cooke BA (1991) Separation and characterization of Leydig cells and macrophages from rat testes Joumal of Endocrinology 130 357-365

Gaytan F, Bellido C, Aceitero J, Aguilar E and Sanchez-Criado JE (1990) Leydig cell involvement in the paracrine regulation of mast cells in the testicular interstitium of the rat Biology of Reproduction 43 665-671

Gaytan F, Aceitero J, Lucena C, Aguilar E, Pinilla L, Garnelo P and Bellido C (1992) Simultaneous proliferation and differentiation of mast cell and Leydig cell in the rat testis. Are common regulatory factors involved? Journal of Andrology 13 387-397

Hutson JC (1990) Changes in the concentration and size of testicular macrophages during development Biology of Reproduction 43 885-890

Jackson MC and Jackson H (1984) Comparative protective actions of gonadotrophins and testosterone against the antispermatogenic action of ethane dimethane sulphonate Journal of Reproduction and Fertility 71 393-401

Jackson AE, O'Leary PC, Ayers MM and de Kretser DM (1986) The effects of ethylene dimethane sulphonate on rat Leydig cells: evidence to support a connective tissue origin of Leydig cells Biology of Reproduction 35 425-437

Kerr JB, Donachie K and Rommerts FFG (1985) Selective destruction and regeneration of rat Leydig cells in vivo Cell and Tissue Research 242 145-156

Kerr JB, Bartlett JMS, Donachie K and Sharpe RM (1987) Origin of regenerating Leydig cells in the testis of the adult rat. An ultrastructural, morphometric and hormonal assay study Cell and Tissue Research 249 367-377

Khan SA, Teerds K and Dorrington JH (1992a) Growth factor requirements for DNA synthesis by Leydig cells from the immature rat Biology of Reproduction 46 335-341

Khan SA, Khan SJ and Dorrington JH (1992b) Interleukin-I stimulates deoxyribonucleic acid synthesis in immature rat Leydig cells in vitro. Endocrinology 131 1853-1856

Le $\mathrm{J}$ and Vilcek J (1987) Tumor necrosis factor and interleukin-1: cytokines with multiple overlapping biological activities Laboratory Investigation 56 234-248

Li H, Hedger MP, Clements JA and Risbridger GP (1991) Localization of immunoreactive $\beta$-endorphin and adrenocorticotropic hormone and pro- opiomelanocortin mRNA to rat testicular interstitial macrophages Biology of Reproduction $45282-289$

Mason MJ and van Epps D (1989) Modulation of IL-I, tumor necrosis factor, C.5A-mediated murine neutrophil migration by $\alpha$-melanocyte-stimulating hormone Journal of Immunology 142 1646-1651

Mauduit C, Chauvin MA, Hartmann DJ, Revol A, Morera AM and Benahmed M (1992) Interleukin- $1 \alpha$ as a potent inhibitor of gonadotropin action in porcine Leydig cells: site(s) of action Biology of Reproduction 46 1119-1126

Meikle AW, Cardoso de Sousa JC, Dacosta N, Bishop DK and Samlowski WE (1992) Direct and indirect effects of murine interleukin-2, gamma interferon, and tumor necrosis factor on testosterone synthesis in mouse Leydig cells Joumal of Andrology 13 437-443

Miller SC, Bowman BM and Rowland H (1983) Structure, cytochemistry, endocytic activity, and immunoglobulin ( $\mathrm{Fc}$ ) receptors of rat testicular interstitial-tissue macrophages American Journal of Anatomy 168 I-13

Molenaar R, de Rooij DG, Rommerts FFG, Reuvers PJ and van der Molen HJ (1985) Specific destruction of Leydig cells in mature rats after in vivo administration of ethane dimethylsulfonate Biology of Reproduction 33 1213-1222

Molenaar R, de Rooij DG, Rommerts FFG and van der Molen HJ (1986) Repopulation of Leydig cells in mature rats after selective destruction of the existent Leydig cells with ethylene dimethane sulphonate is dependent on luteinizing hormone and not follicle-stimulating hormone Endocrinology 118 2546-2554

Morris ID, Phillips DM and Bardin W (1986) Ethylene dimethanesulphonate destroys Leydig cells in the rat testis Endocrinology 118 709-719

Raburn DJ, Coquelin A and Hutson JC (1991) Human chorionic gonadotropin increases the concentration of macrophages in neonatal rat testis Biology of Reproduction 45 172-177

Rappolee DA, Mark D, Banda MJ and Werb Z (1988) Wound macrophages express TGF- $\alpha$ and other growth factors in vivo: analysis by mRNA phenotyping Science 241 708-712

Saez JM, Perrard-Sapori MH, Chatelain PG, Tahone E and Rivarola MA (1987) Paracrine regulation of testicular function Joumal of Steroid Biochemistry 27 317-324

Sharpe RM (1986) Paracrine control of the testis Clinical Endocrinology and Metabolism 15 185-207

Sharpe RM (1990) Intratesticular control of steroidogenesis Clinical Endocrinol ogy $33787-807$

Sharpe RM, Fraser HM and Ratnasoorlyra WD (1988) Assessment of the role of Leydig cell products other than testosterone in spermatogenesis and fertility in adult rats International Journal of Andrology 11 507-523

Skinner MK (1991) Cell-cell interactions in the testis Endocrine Reviews 12 $45-77$

Skinner MK, Takacs K and Coffey RJ (1989) Transforming growth factor-alpha gene expression and action in the seminiferous tubule: peritubular cell-Sertoli cell interactions Endocrinology 124 845-854

Spiteri-Grech J and Nieschlag E (1993) Paracrine factors relevant to the regulation of spermatogenesis - a review Journal of Reproduction and Fertility $981-14$

Syed V, Söder O, Arver S, Linch M and Ritzen EM (1988) Ontogeny and cellular origin of a interleukin-1-like factor in the reproductive tract of the male rat Intermational Journal of Andrology 11 437-447

Teerds KJ, de Rooij DG, Rommerts FFG and Wensing CJG (1988) The regulation of the proliferation and differentiation of rat Leydig cell precursor cells after EDS administration of daily hCG treatment Joumal of Andrology 9 343-351

Teerds KJ, de Rooij DG, Rommerts FFG, van den Hurk R and Wensing CJG (1989a) Stimulation of the proliferation and differentiation of Leydig cell precursors after the destruction of existing Leydig cells with ethane dimethyl sulphonate (EDS) can take place in the absence of LH Journal of Andrology 10 $472-477$

Teerds KJ, de Rooij DG, Rommerts FFG, van den Hurk R and Wensing CJG (1989b) Proliferation and differentiation of possible Leydig cells precursors after destruction of the existent Leydig cells with ethane dimethyl sulphonate (EDS): the role of $\mathrm{LH} /$ human chorionic gonadotrophin Journal of Endocrinology 122 689-696

Teerds KJ, de Rooij DG, Rommerts FFG and Wensing CJG (1990) Development of a new Leydig cell population after the destruction of existing Leydig cells by ethylene dimethane sulphonate in rats: an autoradiographic study Journal of Endocrinology 126 229-236

van Rooijen N (1989) The liposome-mediated macrophage suicide technique Joumal of Immunological Methods 124 1-6

Downloaded from Bioscientifica.com at 04/26/2023 11:15:24AM 
Verhoeven G, Cailleau J, Damme JV and Billiau A (1988) Interleukin I stimulates steroidogenesis in cultured rat Leydig cells Molecular and Cellular Endocrinology $5751-60$

Wahl SM, McCartney-Francis N and Merganhagen SE (1989) Inflammatory and immunomodulatory roles of TGF- $\beta$ Immunology Today 10 258-26I

Welsh TH, Jr and Hsueh AJW (1982) Mechanisms of the inhibitory action of epidermal growth factor on testicular androgen biosynthesis in vitro Endocrinology 110 1498-1503

Xiong $Y$ and Hales DB (1993) The role of tumor necrosis factor- $\alpha$ in the regulation of mouse Leydig cell steroidogenesis Endocrinology 1322438 2444
Xiong Y, Okuno WM and Hales DB (1991) Testicular interstitial macrophages (TIMS) express interleukin-1 mRNA: possible paracrine regulation of P450-17 alpha gene expression in Leydig cells 73rd Annual Meeting of The Endocrine Society, Washington DC, p. 382 (Abstract 1408)

Yee JB and Hutson JC (1985) Effects of testicular macrophage-conditioned medium on Leydig cells in culture Endocrinology 116 2682-2684 